\title{
How protecting a suburban forest as a natural reserve effected small mammal communities
}

\author{
Grzegorz Lesiński • Jakub Benedykt Gryz
}

Published online: 1 July 2011

(C) The Author(s) 2011. This article is published with open access at Springerlink.com

\begin{abstract}
Restoration of mammal communities was studied between 1975-1984 and 2001-2009 (over ca. 30 years) in two suburban forests in central Poland: one protected as a natural reserve and one not protected. The mammal community in the legally protected forest showed more extensive changes than in the case of the nonprotected forest. In the natural reserve, the numbers of Microtus subterraneus, Apodemus agrarius, Rattus norvegicus and Mus musculus decreased while insectivores (mostly Sorex araneus), bats and Apodemus flavicollis increased in numbers. The community of small mammals in the reserve became more similar to the community from the relatively natural area - Białowieża Primeval Forest (eastern Poland). A protection supported restoration processes of tree stands and consequently started to increase the numbers of mammalian species typical of more natural habitats, as well as to reduce the numbers of synanthropic species and those connected to open areas. In the nonprotected forest, fewer species changed their abundance (M. subterraneus decreased, insectivores, bats and A. flavicollis increased). However, an increase in the percentage of bats and a decrease of M. subterraneus in mammal communities of both forests could reflect general trends in their populations noted in recent decades. The population decline of Warsaw's urban species - A. agrarius perhaps is the best indicator of the restoration of suburban forests.
\end{abstract}

Keywords Rodents - Tawny owl $\cdot$ Suburbia $\cdot$ Reserve protection $\cdot$ Habitat restoration Central Europe

G. Lesiński

Department of Functional Food and Commodity, Warsaw University of Life Sciences-SGGW, Nowoursynowska 159 C, 02-776 Warsaw, Poland

e-mail: glesinski@wp.pl

J. B. Gryz $(\bowtie)$

Department of Forest Ecology and Wildlife Management, Forest Research Institute, Sekocin Stary,

Braci Leśnej 3, 05-090 Raszyn, Poland

e-mail: j.gryz@ibles.waw.pl 


\section{Introduction}

Nature conservation efforts face major problems in areas under intensive human activity, especially in cities. Protection-worthy ecosystems usually occur in relatively small patches and are strongly influenced by the surrounding urban habitats. Natural reserves established in the vicinity of cities cannot guarrantee full protection and, if needed, restoration of natural resources. The conservation of animal communities in suburban forests needs to be based on information about the tolerance of various groups to a high level of human activity. For some animals it is also necessary to maintain connections between isolated populations. Many species of small mammals need corridors as they function in metapopulations (Verboom and van Apeldoorn 1990; Kozakiewicz et al. 1993, 1999).

In forests that are connected to urban habitats, restoration processes have rarely been studied, the studies usually focusing on changes in vegetation (Vidra and Shear 2008). Forest floor mammals are strongly dependent on the structure of the plant community. Understory vegetation - herbs and shrubs, as well as woody debris can significantly influence their abundance (Carey and Johnson 1995). Habitat restoration impacts on small mammals have been analysed in a few habitat types (Moro and Gadal 2007; Stone 2007). Some information about changes in mammal communities is given in papers comparing forest habitats exhibiting different patterns of transformation in response to human activity (Sullivan et al. 2000; Fischer and Wilkinson 2005; Yamasaki 2005; Converse et al. 2006; Raoul et al. 2008) or different patterns of fragmentation (Benett 1990; Nupp and Swihart 2000; Schmid-Holmes and Drickamer 2001; Šinkūnas and Balčiauskas 2006).

The aim of this study was to determine the effectiveness of reserve protection using as an example small mammals living in suburban forests. We intended to describe changes taking place over ca. 30 years in two communities of small mammals: one in a protected area and one in an area not subject to nature protection. The expectation was that limiting human penetration and use of some parts of the area due to restrictions resulting from the status of the reserve, together with natural plant succession, could support restoration processes and consequently increase the numbers of species typical of more natural habitats, as well as reduce the numbers of synanthropic species connected to human settlements.

\section{Material and methods}

The study was conducted in suburban forests situated within the administrative borders of the Polish capital city of Warsaw (population ca. 2 million people). Two areas were selected: the Bielany Forest and the Młociny Forest (located $1 \mathrm{~km}$ apart), both bordering on the Vistula river valley. The Bielany Forest is a remnant of a primeval Mazovian forest which covered most of the area of central Poland in early medieval times. Since 17 th century the Bielany Forest has been used as a traditional place of entertainment and, especially in the second half of the 19th century and at the beginning of the 20th century, it was used as a picnic area with a summer cinema and theatre, dancing hall and carousel. Due to intensive human penetration, ground flora and young trees were destroyed, the Bielany Forest became more of a park. In order to prevent further destruction of the forest, 130.35 ha of its area (out of the total of $152 \mathrm{ha}$ ) was placed under legal protection as a nature reserve in 1973 (Rąkowski et al. 
2006). In the wake of this decision, all entertainment facilities were removed, the remaining open areas were afforested, alien species of trees: black locust Robinia pseudoaccacia and red oak Quercus rubra started to be removed, and tourist activities were restricted to marked paths, mostly with wooden fences. As a result this area has regained its previous forest character. Stands, growing on a fertile soil, consist mainly of oaks Quercus spp. (56\%), black alder Alnus glutinosa (17\%) and hornbeam Carpinus betulus $(12 \%)$. Currently stands more than 100 years old predominate in the area, with stands that are 300 years old or more accounting for almost $30 \%$ and some English oaks Quercus robur being more than 400 years old (Zielony 2003; Luniak 2005). The Młociny Forest covers an area of 102.23 ha. Its stands are younger than in the Bielany Forest (mostly below 100 years old) and the dominating species are Scotch pine Pinus silvestris and oaks. It has never been protected as a natural reserve but also has never been subject to intense human pressure. Therefore, it has maintained its typical forest character.

Small mammal communities were analysed in two periods: 1975-1984 and 2001-2009. The occurrence and relative abundance of species were determined using of tawny owl's Strix aluco pellets. This is a strictly sedentary owl, an opportunistic predator, which takes each species belonging to its prey in proportion related to their frequencies in a vertebrate community (Goszczyński 1981; Petty 1999). Home ranges of single pairs may usually reach several tens of hectares (Redpath 1995; Sunde and Bølstad 2004). The population of tawny owls in Warsaw has not changed significantly over the study period (Jabłoński 1991; Gryz 2009).

We used published data from the years 1976-1984, which contained 686 vertebrate prey items, including 423 mammals (Goszczyński et al. 1993), as well as original data supplemented by data from diploma theses (Jasińska 2006; Miłoszewska 2008) from years 2005-2009: 616 vertebrate prey items, including 460 mammals. The results of rodent trapping in standard live-traps were also included into the analysis. We compared the results of a study by Andrzejewski et al. (1978) conducted between 1975-1976 and one conducted by Cichocka (2003) between 2001-2002. As the percentage of birds in the diet of the tawny owl is a good indicator of anthropogenic changes in owls' habitats (Goszczyński et al. 1993; Lesiński et al. 2009), it was additionally calculated and compared between the two study periods.

The determination of species and number of individuals of each prey of tawny owls was based on standard analysis of bone remains, mainly skulls, rarely other bones (eg. the humerus in Talpa europaea). The keys of Pucek (1981) and März (1987) were used. For comparisons of proportions we used the $\chi^{2}$ test in a $2 \times 2$ table, with Yates correction if at least one number was below 10. In order to evaluate differences between two mammal communities we calculated the sum of differences between the percentages of each species.

\section{Results}

Eighteen species of small mammals (bats were represented by five species: Eptesicus serotinus, Nyctalus noctula, N. leisleri, Pipistrellus nathusii, Plecotus auritus) were captured by tawny owls in the forests under study (Table 1). In both areas A. agrarius was the most abundant species in the diet between 1976-1984, while A. flavicollis was dominant between 2005-2009. M. glareolus was relatively abundant (from 14.2 to $21.9 \%$ ) in both communities under study, M. subterraneus was relatively abundant in the first study 
Table 1 Mammalian prey of the tawny owl in two forests in two study periods (only those individuals identified to species were included)

\begin{tabular}{|c|c|c|c|c|c|c|c|c|}
\hline \multirow[t]{3}{*}{ Species } & \multicolumn{4}{|c|}{ 1976-1984 } & \multicolumn{4}{|c|}{ 2005-2009 } \\
\hline & \multicolumn{2}{|c|}{ Bielany Forest (P) } & \multicolumn{2}{|c|}{ Młociny Forest (NP) } & \multicolumn{2}{|c|}{ Bielany Forest $(\mathrm{P})$} & \multicolumn{2}{|c|}{ Młociny Forest (NP) } \\
\hline & $\mathrm{N}$ & $\%$ & $\mathrm{~N}$ & $\%$ & $\mathrm{~N}$ & $\%$ & $\mathrm{~N}$ & $\%$ \\
\hline Talpa europaea & 2 & 1.1 & 2 & 0.9 & 3 & 1.2 & 3 & 2.9 \\
\hline Sorex araneus & 2 & 1.1 & 6 & 2.6 & 16 & 6.3 & 10 & 9.6 \\
\hline Sorex minutus & 0 & 0 & 0 & 0 & 0 & 0 & 1 & 1.0 \\
\hline Neomys fodiens & 0 & 0 & 1 & 0.4 & 0 & 0 & 0 & 0 \\
\hline Chiroptera & 0 & 0 & 0 & 0 & 12 & 4.8 & 4 & 3.8 \\
\hline Myodes glareolus & 27 & 14.2 & 51 & 21.9 & 45 & 17.9 & 18 & 17.3 \\
\hline Microtus subterraneus & 20 & 10.5 & 42 & 18.0 & 4 & 1.6 & 2 & 1.9 \\
\hline Microtus arvalis & 15 & 7.9 & 16 & 6.9 & 12 & 4.8 & 0 & 0 \\
\hline Microtus oeconomus & 0 & 0 & 4 & 1.7 & 1 & 0.4 & 0 & 0 \\
\hline Rattus norvegicus & 2 & 1.1 & 1 & 0.4 & 1 & 0.4 & 1 & 1.0 \\
\hline Mus musculus & 7 & 3.7 & 2 & 0.9 & 0 & 0 & 0 & 0 \\
\hline Micromys minutus & 0 & 0 & 6 & 2.6 & 1 & 0.4 & 5 & 4.8 \\
\hline Apodemus agrarius & 90 & 47.4 & 53 & 22.7 & 33 & 13.1 & 17 & 16.3 \\
\hline Apodemus flavicollis & 25 & 13.2 & 49 & 21.0 & 124 & 49.2 & 43 & 41.3 \\
\hline Total & 190 & 100.0 & 233 & 100.0 & 252 & 100.0 & 104 & 100.0 \\
\hline
\end{tabular}

$P$ protected as a natural reserve, $N P$ not protected

period. S. minutus and $N$. fodiens were recorded only in the Młociny Forest. Bats Chiroptera occurred exclusively in the samples collected in the latter period.

There were statistically significant differences in the abundance of some species of mammals in the diet of tawny owls (Table 2). The numbers of M. subterraneus decreased while insectivores (mostly $S$. araneus), bats and A. flavicollis increased in numbers in both forests. But it should be mentioned that an increasing rate for strictly forest species (A. flavicollis) were more pronounced in protected area: from $13.2 \%$ to $49.2 \%$ vs. $21.0 \%$ and $41.3 \%$ in nonprotected forest (Table 1 ). The numbers of synanthropic species ( $R$. norvegicus and $M$. musculus) as well as A. agrarius decreased only in the Bielany Forest.

The proportions of $A$. agrarius and A. flavicollis in both areas differed over ca. 30 years: in the Bielany Forest it was 90:25 in the period 1976-1984 and 33:124 in 2005-2009, $\chi^{2}=87.8$, d.f. $=1, P<0.001$; in the Młociny Forest it was 53:49 in 1976-1984 and 17:43 in 2007-2009, $\chi^{2}=8.6$, d.f. $=1, P=0.003$. The difference between total abundance of mammal communities of the Bielany Forest and the Młociny Forest in the years 1976-1984 was higher (sum of differences calculated for individual species - 57.6\%) than in the years 2005-2009 (29.2\%). Similar differences calculated for a single area between the two study periods were higher in the Bielany Forest (101.3\%) as compared to the Młociny Forest $(73.9 \%)$.

The percentage of $A$. agrarius in the mammal communities in the forests decreased also in the trapping data. A comparison of the proportion of the number of A. agrarius to the number of other rodents revealed statistically important differences. In the Bielany Forest: 488:252 in $1975-1976$ vs. $3: 28$ in $2001, \chi^{2}=38.34$, d.f. $=1, P<0.001$; in the Młociny Forest: $377: 418$ in $1975-1976$ vs. $10: 167$ in $2001-2002$, $\chi^{2}=105.42$, d.f. $=1, P<0.001$. 
Table 2 Comparison of the proportion of selected species or groups of species to remaining mammalian prey of the tawny owl in the area protected by natural reserve (Bielany Forest) and without protection (Młociny Forest)

\begin{tabular}{|c|c|c|c|c|c|c|c|c|}
\hline \multirow[t]{2}{*}{ Taxon } & \multicolumn{2}{|c|}{ Bielany Forest $(P)$} & \multirow[t]{2}{*}{$\chi^{2}$ d.f. $=1$} & \multirow[t]{2}{*}{$P$} & \multicolumn{2}{|c|}{ Młociny Forest $(N P)$} & \multirow[t]{2}{*}{$\chi^{2}$ d.f. $=1}$, & \multirow[t]{2}{*}{$P$} \\
\hline & 1976-1984 & 2005-2009 & & & $1976-1984$ & 2007-2009 & & \\
\hline Talpa europaea & 2: 188 & $3: 249$ & 0.1 & 0.750 & $2: 231$ & $3: 101$ & 0.9 & 0.351 \\
\hline Sorex araneus & $2: 188$ & $16: 236$ & 6.5 & 0.011 & $6: 227$ & $10: 94$ & 6.4 & 0.011 \\
\hline Sorex minutus & $0: 190$ & $0: 252$ & $\mathrm{X}$ & $\mathrm{X}$ & $0: 233$ & $1: 103$ & 0.2 & 0.678 \\
\hline Neomys fodiens & $0: 190$ & $0: 252$ & $\mathrm{X}$ & $\mathrm{X}$ & $1: 232$ & 0:104 & 0.2 & 0.678 \\
\hline Insectivora total & $4: 186$ & $19: 233$ & 5.4 & 0.020 & $9: 224$ & $14: 90$ & 9.0 & 0.003 \\
\hline Chiroptera & $0: 190$ & $12: 240$ & 7.6 & 0.006 & $0: 233$ & $4: 100$ & 6.1 & 0.014 \\
\hline Myodes glareolus & $27: 163$ & $45: 207$ & 1.1 & 0.304 & $51: 182$ & $18: 86$ & 0.9 & 0.336 \\
\hline Microtus subterraneus & $20: 170$ & $4: 248$ & 15.2 & $<0.001$ & $42: 191$ & $2: 102$ & 15.0 & $<0.001$ \\
\hline Microtus arvalis & $15: 175$ & $12: 240$ & 1.4 & 0.246 & $16: 217$ & $0: 104$ & 6.1 & 0.014 \\
\hline $\begin{array}{l}\text { Microtus } \\
\text { oeconomus }\end{array}$ & $0: 190$ & $1: 251$ & 0.0 & 0.887 & $4: 229$ & $0: 104$ & 0.6 & 0.424 \\
\hline $\begin{array}{l}\text { Rattus norvegicus }+ \\
\quad \text { Mus musculus }\end{array}$ & $9: 181$ & $1: 251$ & 7.4 & 0.007 & $3: 230$ & $1: 103$ & 0.1 & 0.772 \\
\hline Apodemus agrarius & $90: 100$ & $33: 219$ & 63.4 & $<0.001$ & $53: 180$ & $17: 87$ & 1.8 & 0.181 \\
\hline Apodemus flavicollis & $25: 165$ & $124: 128$ & 63.0 & $<0.001$ & $49: 184$ & $43: 61$ & 15.0 & $<0.001$ \\
\hline
\end{tabular}

$P$ protected as a natural reserve, $N P$ not protected

Statistically important differences in bold. X - not calculated

As for the frequency with which birds were captured by tawny owls, the only data from Bielany Forest varied significantly between the two study periods: 142:194 in 1976-1984 vs. $104: 340$ in $2005-2009, \chi^{2}=31.4$, d.f. $=1, P<0.001$, Młociny Forest: $63: 287$ in 19761984 vs. $42: 130$ in $2007-2009, \chi^{2}=3.0$, d.f. $=1, P=0.086$, NS.

\section{Discussion}

Our study proved changes in the structure of small mammal communities in two suburban forests over 30 years. When comparing two study periods more expressed differences were obtained for protected area. They mostly concerned the reduction of numbers of a species typical for open habitats (A. agrarius) and synanthropic species $(R$. norvegicus and M. musculus). Some mammals showed similar changes in both forests under study: M. subterraneus (decreasing) while Soricidae, Chiroptera and A. flavicollis (increasing).

Tawny owls living in a national park established in Białowieża Primeval Forest (eastern Poland), the most natural lowland forest in central Europe, took their main mammalian prey in different proportions (Jędrzejewski et al. 1994) than their counterparts in the suburban forests under study (Table 3). The three most abundant species or groups of species in Białowieża Forest were: M. glareolus, A. flavicollis and Soricidae. A. agrarius was not listed as a food item. If present, it was probably included in the group of "other rodents", but their contribution to mammalian prey was low (2.6\%). The absence of $A$. agrarius in the Białowieża National Park was confirmed by trapping (Aulak 1970). Decreasing numbers of this field mouse as well as strictly synanthropic species (M. musculus, $R$. norvegicus) along with increasing numbers of the typically forest-dwelling $A$. flavicollis 
Table 3 Percentages in which selected species or groups of species were captured by tawny owls in Bielany Forest (before and after protection) and in Białowieża Primeval Forest, $N=2447$ mammalian prey items (Jędrzejewski et al. 1994)

\begin{tabular}{lccc}
\hline Taxon & $\begin{array}{l}\text { Bielany Forest }- \\
\text { before protection }\end{array}$ & $\begin{array}{l}\text { Bielany Forest }- \\
\text { after protection }\end{array}$ & $\begin{array}{l}\text { Białowieża Primeval } \\
\text { Forest }\end{array}$ \\
\hline Soricidae & 1.1 & 6.3 & 23.6 \\
Myodes glareolus & 14.2 & 17.9 & 36.8 \\
Microtus subterraneus & 10.5 & 1.6 & 4.0 \\
Apodemus flavicollis & 13.2 & 49.2 & 30.6 \\
Other rodents & 60.1 & 19.1 & 2.6 \\
(including Apodemus agrarius) & $(47.4)$ & $(13.1)$ & $(?)$ \\
\hline
\end{tabular}

and insectivores in the Bielany Forest over 30 years of protection seem to indicate the beggining of restorative processes in the community of small mammals.

In Warsaw, A. agrarius has a tendency to colonize parks in different zones of the city and it forms abundant urban populations. This phenomenon was first described ca. 30 years ago (Andrzejewski et al. 1978). At present the species still occurs in large numbers in the central parks and is the dominant species in rodent communities, accounting for nearly $60 \%$ of individuals (data from the pellet composition analysis - Gryz et al. 2008). In the Bielany Forest it has shown just a local decline during the last few decades, which could support the hypothesis that restoration processes are taking place in this area.

However, the similar changes observed in some species in both forests under study seem to reflect general tendencies, not connected with a protection status. The numbers of $M$. subterraneus fell, and this phenomenon could be typical for peripheral Warsaw as Gryz et al. (2008) did not observe significant changes in central districts of the city. Moreover, the increasing of A. flavicollis should not be interpreted as strongly dependent on the potection but it should be mentioned that changes observed in a protected area were more pronounced.

The percentage of bats in owls' diet showed important changes within the study period, remarkable findings including their total absence in the years 1976-1984 and the presence of a few individuals in years 2005-2009 (Table 1). This figure should not be interpreted as a corollary of forest restoration. Bats appeared to be very sensitive to the mass use of toxic pesticides that took place in Poland from the 1960s. The lowest abundance of bat assemblages was noted from the early 1980 s with a slowly increasing tendency in the last few decades (Węgiel et al. 2001; Lesiński et al. 2005, 2008).

A similar study of restoration processes focusing on birds in the Bielany Forest between 1988-2000 (Mazgajski et al. 2001) showed slight differences, mostly with regard to species associated with the layer of small trees and shrubs (increasing tendency) and hole nesters (decreasing tendency). At the end of the study period the avian community was found to be at a stage between urban parks and natural deciduous forests. The mammalian community in the present study was followed up over a longer period and therefore the differences were much higher.

The results of our study showed that within just three decades changes in the small mammal community following the acquisition of the legally protected status could be observed and could reflect the restoration of forest biocenoses. The hypothesis of a population decline in species associated with habitats transformed by human activity was supported. 
Open Access This article is distributed under the terms of the Creative Commons Attribution Noncommercial License which permits any noncommercial use, distribution, and reproduction in any medium, provided the original author(s) and source are credited.

\section{References}

Andrzejewski R, Babińska-Werka J, Gliwicz J, Goszczyński J (1978) Synurbization processes in population of Apodemus agrarius I. Characteristics of populations in an urbanization gradient. Acta Theriol 23:341358

Aulak W (1970) Small mammal communities of the Białowieża National Park. Acta Theriol 15:465-515

Benett AF (1990) Habitat corridors and the conservation of small mammals in a fragmented forest environment. Lands Ecol 4:109-122

Carey AB, Johnson ML (1995) Small mammals in managed, naturally young, and old-growth forests. Ecol Appl 5:336-352

Cichocka A (2003) Small mammals of green areas of Warsaw. Dissertation, Warsaw University of Life Sciences (in Polish with English summary)

Converse SJ, Block WM, White GC (2006) Small mammal population and habitat responses to forest thinning and prescribed fire. Forest Ecol Manage 228:263-273

Fischer JT, Wilkinson L (2005) The response of mammals to forest fire and timber harvest in the North American boreal forest. Mammal Rev 35:51-81

Goszczyński J (1981) Comparative analysis of food of owls in agrocenoses. Ekol Pol 29:431-439

Goszczyński J, Jabłoński P, Lesiński G, Romanowski J (1993) Variation in diet of Tawny Owl Strix aluco L. along an urbanization gradient. Acta Orn 27:13-123

Gryz J (2009) Environmental determinants of diet composition and reproduction of tawny owl Strix aluco Linnaeus 1758. PhD Dissertation, Warsaw University of Life Sciences - SGGW (in Polish with English summary)

Gryz J, Krauze D, Goszczyński J (2008) The small mammals of Warsaw as inferred from tawny owl (Strix aluco) pellet analyses. Ann Zool Fenn 45:281-285

Jabłoński P (1991) Distribution of Tawny Owl Strix aluco in Warsaw. Acta Orn 26:31-38

Jasińska K (2006) Synurbanization process of Tawny Owl (Strix aluco) in Warsaw. Dissertation, Warsaw University of Life Sciences - SGGW (in Polish with English summary).

Jędrzejewski W, Jędrzejewska B, Zub K, Ruprecht AL, Bystrowski C (1994) Resource use by Tawny Owls Strix aluco in relation to rodent fluctuations in Białowieża National Park, Poland. J Avian Biol 25:308-318

Kozakiewicz M, Kozakiewicz A, Łukowski A, Gortat T (1993) Use of space by bank voles (Clethrionomys glareolus) in a polish farm landscape. Lands Ecol 8:19-24

Kozakiewicz M, Gortat T, Kozakiewicz A, Barkowska M (1999) Effects of habitat fragmentation on four rodent species in a Polish farm landscape. Lands Ecol 14:391-400

Lesiński G, Fuszara E, Fuszara M, Jurczyszyn M, Urbańczyk Z (2005) Long-term changes in numbers of the barbastelle Barbastella barbastellus (Schreber 1774) in Poland. Folia Zool 54:351-358

Lesiński G, Gryz J, Kowalski M (2008) Does the diet of an opportunistic raptor, the tawny owl Strix aluco, reflect long-term changes in bat abundance? A test in central Poland. Folia Zool 57:258-263

Lesiński G, Błachowski G, Siuchno M (2009) Vertebrates in the diet of the tawny owl Strix aluco in northern Podlasie (NE Poland) - comparison of forest and rural habitats. Fragm Faun 52:51-59

Luniak M (2005) Bielany forest. Las Bielański. In: Wojtatowicz J (ed) Warsaw's nature - protected areas and sites. Warszawska przyroda - obszary i obiekty chronione. Biuro Ochrony Środowiska Urzędu m. st. Warszawy, Warsaw (in Polish)

März R (1987) Gewöll- und Rupfungskunde. 3., neu von Konrad Banz bearbeitete Auflage. AkademieVerlag, Berlin

Mazgajski TD, Rejt Ł, Chromy M, Podlacha F (2001) Present status and changes in avifauna composition in "Bielański Forest" reserve. Parki Nar Rez Przyr 20:27-41 (in Polish with English summary)

Miłoszewska AI (2008) Composition and seasonal food variation of Tawny Owl Strix aluco in Warsaw. Dissertation, Warsaw University of Life Sciences - SGGW (in Polish with English summary)

Moro D, Gadal S (2007) Benefits of habitat restoration to small mammal diversity and abundance in a pastoral agricultural landscape in mid-Wales. Biodivers Conserv 16:3543-3557

Nupp TE, Swihart RK (2000) Lanscape-level correlates of small-mammal assemblages in forest fragments of farmland. J Mammal 81:512-526

Petty SJ (1999) Diet of tawny owls (Strix aluco) in relation to field vole (Microtus agrestis) abundance in a conifer forest in northern England. J Zool 248:451-465 
Pucek Z (1981) Keys to vertebrates of Poland. Mammals. PWN, Warsaw

Rąkowski G, Walczak M, Smogorzewska M (2006) Natural reserves in Central Poland. Rezerwaty przyrody w Polsce Środkowej. Wydawnictwo Naukowe Gabriel Borowski, Lublin (in Polish)

Raoul F, Pleydell D, Quéré JP, Vaniscotte A, Rieffel D, Takahashi K, Bernard N, Wang J, Dobigny T, Galbreath KE, Giraudoux P (2008) Small-mammal assemblage response to deforestation and afforestation in central China. Mammalia 72:320-332

Redpath SM (1995) Habitat fragmentation and the individual: tawny owls Strix aluco in woodland patches. J Anim Ecol 64:652-661

Schmid-Holmes S, Drickamer LC (2001) Impact of forest patch characteristics on small mammal communities: a multivariate approach. Biol Conserv 99:293-305

Šinkūnas R, Balčiauskas L (2006) Small mammal communities in the fragmented landscape in Lithuania. Acta Zool Lit 16:130-136

Stone ER (2007) Measuring impacts of restoration on small mammals in a mixed-grass Colorado prairie. Ecol Res 25:183-190

Sullivan TP, Sullivan DS, Lindgren PMF (2000) Small mammals and stand structure in young pine, seed-tree, and old-growth forest, southwest Canada. Ecol Appl 10:1367-1383

Sunde P, Bølstad MS (2004) A telemetry study of the social organization of a tawny owl (Strix aluco) population. J Zool 263:65-76

Verboom B, van Apeldoorn R (1990) Effects of habitat fragmentation on the red squirel Sciurus vulgaris. Lands Ecol 4:171-176

Vidra RL, Shear TH (2008) Thinking locally for urban forest restoration: a simple method links exotic species invasion to local landscape structure. Res Ecol 16:217-220

Węgiel A, Grzywiński W, Adamus P, Sadowy R, Wieczorek M (2001) Bats (Chiroptera) hibernating in the caves of the Kraków Upland. Nietoperze 2:23-42 (in Polish with English summary)

Yamasaki M (2005) Bats and small mammals in old growth habitats in the White Mountains. In: Proc. of the conference "Moving toward sustainable forestry: lessons from old growth forests" Univ. of New Hampshire: $62-63$

Zielony R (2003) Kabacki Forest on the background of natural areas under protection within Warsaw' borders. Las Kabacki na tle przyrodniczych obiektów prawnie chronionych w granicach Warszawy. In: Czerwiński Z, Czępińska-Kamińska D, Zielony R (eds) Natural. resources of Kabacki Forest. Środowisko przyrodnicze Lasu Kabackiego. Wydawnictwo SGGW, Warsaw (in Polish) 